\title{
TWO PANDEMICS COALITION: COVID-19 AND OBESITY
}

\author{
Anca Hâncu¹, Florin Mihălțan² \\ ${ }^{1}$ Nutriscience Clinic, Bucharest \\ 2"Carol Davila" University, Bucharest
}

\begin{abstract}
COVID-19 epidemic caused by an influenza-like virus strain (SARS-CoV-2) invaded the world. The World Health Organization (WHO) announced this infection outbreak as a global pandemic on 11 March 2020. From one day to another the number of new cases is growing and also the number of deaths. This infection emerged earlier in Wuhan City and rapidly spread throughout China and around the world since December 2019. Another silent pandemic disease spreading mainly in industrialized countries is obesity. The best example is US were about $34 \%$ of the Americans are obese.

In actual context, it can be said there is a coalition of 2 pandemics. In Romania, obesity and overweight prevalence assessed by Predatorr study is at a high level: 34,7\% overweight and $31,9 \%$ obesity. Systemic inflammation in obesity is the central mechanism leading to lung function decline. There are two main questions a) is obese more sensible to viral infection or $b$ ) potentially more contagious? The answer is positive to both. Recent WOF official position stated that obesity is a risk factor for developing severe forms of COVID-19. Donna Ryan's message, as president of World Obesity Federation WOF, US emphasized at the beginning of April the risk for severe complications for persons with obesity who contracted the infection with SARS-CoV-2. Nutritional support in COVID-19 should prefer oral feeding, whenever is possible. A special attention should be dedicated to a healthy microbiome and intestinal immunity. Energy intake should be $25-30 \mathrm{kcal} /$ body weight, with $1.2-2 \mathrm{~g} / \mathrm{kg}$ proteins. Enteral nutrition will be recommended in severe cases. Evidence is supporting the recommendation that for people at risk of developing COVID-19 to consider for few weeks a dosage of 10000 UI/day of vitD3, than a maintainance dose of $5000 \mathrm{UI} /$ day. The target must be to stabilize a level of $40-60 \mathrm{ng} / \mathrm{ml}$ for $25(\mathrm{OH}) \mathrm{D}$ concentration. Pulmonary rehabilitation, smoking cessation, included in a healthy lifestyle will be further steps after patients recovery from this infection. Facing this pandemic coalition, our messages should be stronger in stimulating prevention of obesity. Since more than a half of Romanian population is already overweight or obese, healthy lifestyle should become a daily prescription, not just a luxury recommendation. Daily, right messages from doctors acting like role models, in a partnership between general practitioner and other specialties like diabetologists, pneumologists, cardiologists, nutritionists will be efficient weapons against this cruel coalition: Obesity and COVID 19.
\end{abstract}

Keywords: lung function decline, obesity, COVID 19, inflammation, immunity, risk factors. 


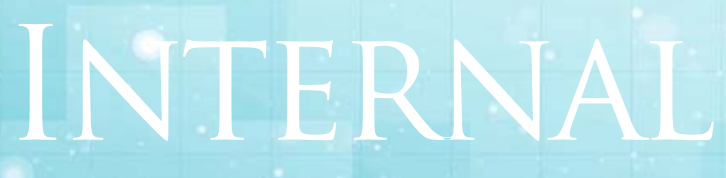

General Reviews

\section{Rezumat}

Epidemia de COVID-19, cauzată de o tulpină virală asemănătoare gripei (SARS-CoV-2), a invadat lumea. Pe data de 11 martie 2020, Organizația Mondială a Sănătății (OMS) a anunțat pandemia globală. De la o zi la alta, numărul de cazuri noi este în creștere și, de asemenea, numărul de decese. Această infecție a apărut inițial în orașul Wuhan și s-a răspândit rapid în China și în întreaga lume, începând cu luna decembrie 2019.

O altă pandemie silențioasă care se răspândește în principal în țările industrializate este obezitatea. Cel mai bun exemplu este SUA, aproximativ 34\% dintre americani fiind obezi.

În contextul actual, se poate spune că există o coaliție de două pandemii. În România, prevalența obezității și supraponderalității, evaluate de studiul Predatorr, sunt ridicate: 34,7\% persoane supraponderale și 31,9\% persoane obeze. Inflamația sistemică din obezitate este mecanismul central care determină scăderea funcției pulmonare. Există două întrebări principale a) este persoana obeză mai sensibilă la infecția virală sau b) potențial mai contagioasă? Răspunsul este pozitiv pentru ambele. Poziția oficială recentă a WOF a stabilit că obezitatea este un factor de risc pentru dezvoltarea formelor severe de COVID-19. Prin mesajul său, Donna Ryan, în calitate de președinte al World Obesity Federation WOF, SUA, a subliniat la începutul lunii aprilie riscul de complicații severe pentru persoanele obeze care au contactat infecția cu SARS-CoV-2.

Suportul nutrițional în COVID-19 ar trebui să se administreze, ori de câte ori este posibil, pe cale orală. O atenție specială ar trebui să fie dedicată unui microbiom sănătos și imunității intestinale. Aportul de energie trebuie să fie de 25-30 kcal/kg greutate corporală, cu 1,2-2 g/kg proteine. Nutriția enterală se va recomanda în cazurile severe. Dovezile științifce susțin recomandarea ca, persoanelor cu risc de a contacta COVID-19, să li se administreze o doză de 10000 UI/zi de VitD3 pentru câteva săptămâni, apoi o doză de întreținere de 5000 UI/zi. Ținta trebuie să fie stabilizarea concentrației serice de $25(\mathrm{OH})$ D la 40-60 ng/ml. Reabilitarea pulmonară, renunțarea la fumat, ca parte a unui stil de viață sănătos, vor fi pași suplimentari pentru recuperarea pacienților după această infecție.În fața acestei coaliții pandemice, mesajele noastre ar trebui să fie mai puternice în sensul prevenirii obezității. Întrucât mai mult de jumătate din populația română este deja supraponderală sau obeză, stilul de viață sănătos ar trebui să devină o rețetă zilnică, nu doar o recomandare de lux. Mesajele corecte de la medici care acționează ca modele, într-un parteneriat între medicul generalist și alte specialități precum diabetologi, pneumologi, cardiologi, nutriționiști vor fi arme eficiente împotriva acestei coaliții crude: obezitatea și COVID 19.

Cuvinte cheie: declinul funcției pulmonare, obezitate, COVID 19, inflamație, imunitate, factori de risc. 


\section{Introduction: COVID 19, actual context}

COVID-19 epidemic caused by an influenzalike virus strain (SARS-CoV-2) invaded the world. The World Health Organization (WHO) announced this infection outbreak as a global pandemic on 11 March $2020^{(1)}$. From one day to another the number of new cases is growing and also the number of deaths. This infection emerged earlier in Wuhan City and rapidly spread throughout China and around the world since December $2019^{(2)}$.

\section{Obesity, pandemic crisis}

Another silent pandemic disease spreading mainly in industrialized countries is obesity. The best example is US were about $34 \%$ of the Americans ${ }^{(3)}$ are obese and, yearly between 160 to 210 million Americans are becoming obese with risk of infection ${ }^{(4)}$. When these two diseases are coming together the life of these patients is changing totally. The package seems more complex if we are thinking that obesity is accompanied by diabetes mellitus, sleep apnea syndrome or surfactant dysfunction ${ }^{(5)}$.

In actual context, it can be said there is a coalition of 2 pandemics. In Romania, obesity and overweight prevalence assessed by Predatorr study ${ }^{(6)}$ is at a high level: $34,7 \%$ overweight and $31,9 \%$ obesity and actual evolution of noncommunicable diseases related to obesity is becoming more and more a healthcare issue.

\section{Lung function decline in obesity, inflammation and immunity, obesity and lung function}

Systemic inflammation in obesity is the central mechanism leading to lung function decline. Adipokines are secreted by adipose tissue, which in fact is an endocrine organ. They are supposed to affect airway function. Adipokines are expressed differently in lean versus obese patients, in asthmatic vs nonasthmatic patients. Adiponectin has the highest anti-inflammatory action from adipokines and its expression is reduced in adipose tissue. In contrast, leptin, the proinflammatory adipokine is increased in asthmatic obese patients ${ }^{(7)}$. Leptin is a key driver, modulating ventilatory activity, surfactant production, but also increases metabolism and regulates immunity ${ }^{(8,9)}$. A strong correlation between visceral fat leptin concentrations and airways hyperresponsiveness has been found.

Inflammatory mediators are elevated in obesity, mainly C reactive protein, IL8, IL6, TNF alfa. Different studies have investigated if there is a link between increased airway inflammation and circulating citokines and adipokines described at obese persons. More and more evidences are supporting that the adipose tissue is the generator of the chronic inflammation concomitant with airway diseases and abnormal lung function. Not yet explained is the effect of all these systemic factors on structural airways cells. Obese patients have an increased susceptibility in developing bacterial or influenza pneumonia ${ }^{(10,11)}$.

The imbalance in adipokine levels, induced by obesity may affect vascular endothelial function at pulmonary level, preparing the lung for injury ${ }^{(12)}$. Metabolic dysregulations dyslipidemia and insulin resistance- present usually in obesity are enhancing airways smooth muscle ASM proliferation and epithelial damage ${ }^{(13)}$ which will turn to airways hyperresponsiveness AHR. Metabolic syndrome and diabetes have been already associated with an impaired lung function ${ }^{(14,15)}$. 


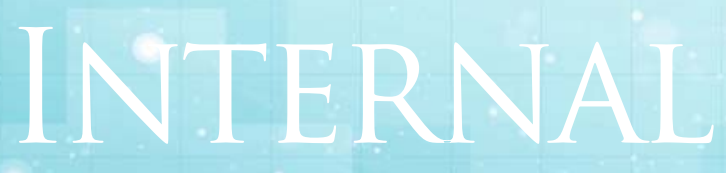

\section{General Reviews}

The restrictive pattern is usually linked to metabolic dysregulations from obesity ${ }^{(16)}$. This link is bidirectional, restrictive lung disease being also correlated with insulin resistance.

European Community Respiratory Health Survey ECRHS is the reference ${ }^{(17)}$ evidence for lung function decline associated to weight increase. Along a follow-up period of 20 years, moderate and light weight gain were associated with important declines of pulmonary function, evidenced by FEV 1 and FVC decrease. This result was observed for normal BMI, but also for obese and overweight patients at starting point. No association was confirmed between weight increase and FEV1 / FVC ratio suggesting that the decline is on restrictive pathway, not obstructive.

At obese persons, the reaction of immune cells is significantly disturbed in adipose tissue. In the subcutaneous tissue from obese individuals, Weisberg isolated more than $50 \%$ macrophages ${ }^{(18)}$. Other authors, like Sideleva reported an increased infiltration with macrophages, both in subcutaneous tissue and in visceral adipose tissue in obese persons with asthma associated $^{(7)}$. Peryalill found macrophages of a pro-inflammatory type ${ }^{(19)}$. Known mainly as allergy mediators, mast cells may proliferate in obesity, potentially explaining another mechanism for respiratory diseases. These cellular aspects may explain immune deficit observed at obese people that constitute a higher predisposition.

\section{Obesity and SARS-COV-2 infection susceptibility}

There are two main questions a) is obese more sensible to viral infection or $b$ ) potentially more contagious? Susceptibility to infections of overweigh patients remains a challenging problem if we are looking to the complementary actions of the associated comorbidities. The worse scenario is based on many possible evidence. First of all, these patients had in many cases type 2 diabetes and are at age over $65^{(20)}$. Another possible explanation is coming from this important link between inflammation and alteration at different of the innate and adaptive immune response(21). Inflammation inducing dysregulation of the immune response is based on chronically higher leptin (a proinflammatory adipokine) and lower adiponectin (an anti-inflammatory adipokine) concentrations ${ }^{(22)}$. Another supplementary acting factor on immune response is a higher concentration of several pro-inflammatory cytokines like alpha-TNF, MCP-1 and IL-6, mainly produced by visceral and subcutaneous adipose tissue ${ }^{(23)}$. All this is acting on the macrophage reducing his activation when an antigen is 
presented and blunting the proinflammatory cytokine production upon macrophage stimulation ${ }^{(24)}$. To all these problems the sensibility of obese to COVID 19 is also induced by: poor vaccination success and by impaired answer of $B$ and $T$ cells responses, as has been shown in influenza infections ${ }^{(25)}$. Leptin resistance was present as cofactor also in other infections like:H1N1 pandemic influenza. The immunological response of obese patients is impaired also by: physical inactivity ${ }^{(26)}$.

Other factors worsening the clinical evolution of COVID 19 infection in obese patients are: the dynamic of pulmonary ventilation in these subjects, with reduced diaphragmatic excursions and a relative increase in anatomical death space ${ }^{(27)}$.

b) The answer at the second question is also positive. The obese is more contagious because, probably, like in influenza infections, the individual is shedding for longer time the virus ${ }^{(28)}$. Obese persons have also a delayed capacity to produce interferon ${ }^{(29)}$ and body mass index correlates positively with infectious virus in exhaled breath $^{(30)}$.

\section{Obesity as a poor prognosis factor in COVID 19}

Recent WOF official position stated that obesity is a risk factor for developing severe forms of COVID-19. Donna Ryan's message, as president of WOF, US emphasized at the beginning of April the risk for severe complications for persons with obesity who contracted the infection with SARS-CoV- $2^{(31)}$. Presence of obesity below the age of 60 is a risk factor for hospital admission due to new SarS-CoV-2 infection, is stated in a new research published in USA. Recognizing obesity as a risk factor is important in establishing prevention populational strategies and in recognizing high risk target groups $^{(32)}$. From 3615 positively tested for COVID-19, obesity grade I has been described at $21 \%$ (775) and grade II at $16 \%$ (595). The admission rate to an intensive care was $12 \%$. Meaningful differences could be recognized in patients younger than $60 \mathrm{y}$ according to their $\mathrm{BMI}^{(32)}$. Obesity grade I was described 1.8 times highly associated for younger patients admitted to ICU versus normal weight or overweight patients. The rate increased at 2.2 for obesity grade II. Despite the fact that patients below 60 have been initially considered at low risk, higher hospital admission rate for younger obese people vs normal weight people at the same age is revealing obesity as an independently risk factor, unrecognized before.

The Lille Intensive Care COVID-19 and Obesity study group described a high prevalence of obesity in patients with severe acute respiratory syndrome coronavirus-2 (SARS-CoV-2) requiring invasive mechanical ventilation (33). They performed a retrospective cohort study, establishing a relation between $\mathrm{BMI}$ and the need of invasive mechanical ventilation IMV. The cohort realized was in a single center in France. $75.8 \%$ from patients admitted to hospital were obese and $68.6 \%$ requiring IMV. By each BMI category, the proportion of patients ventilated increased accordingly. Interestingly, the highest significantly association was with male sex and BMI ( $p$ $<0.05$ ) independent of hypertension, diabetes or age. This study is showing a high percentage of obesity in intensive care units and is an evidence that increased BMI is associated with disease severity, drawing the conclusion that obesity per se is an independent risk factor for COVID 19 severity and possible dangerous evolution will require 


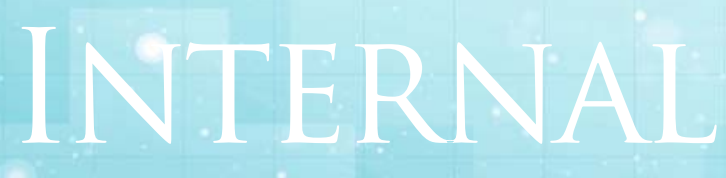

General Reviews

special attention and preventive measures for obese people. These findings are in line with previous reports that obesity is a predisposition factor for developing a severe H1N1 respiratory infection. Based on these, what should be changed? Avoiding contamination should be enforced by preventive measures during this pandemic period and further studies will explain better the influence of obesity on SARS-COV-2 evolution. Early descriptions of high risks for developing severe forms of SARS-COV-2 infection included cardiovascular disease, chronic respiratory diseases, hypertension, cancers $^{(34)}$ but obesity or BMI was neglected in clinical reports, despite the fact that obesity was described independently as a risk factor for H1N1 severe infection ${ }^{(35)}$. As WOF is emphasizing, obesity should be considered as a major risk factor for COVID19 susceptibility, contagiosity and evolution through severe forms.

\section{Microbiome and COVID-19}

In the guidelines elaborated by Zhejiang University ${ }^{(36)}$ an entire chapter is dedicated to intestinal microecology balance and nutritional support. It has been described an alteration in microbial balance at COVID-19 patients, with significant decrease in bifidobacterium and lactobacillus. Leaky gut may lead to bacterial translocation and secondary bacterial infection. The importance of maintaining a healthy gut is obvious. Micro ecologic interventions will reduce bacterial translocations, increasing positive bacteria, with consecutive toxin production reduction. The infection produced by gut bacterial dysbiosis could be stopped. Gastrointestinal symptoms described in the infection with SARS-COV-2 like diarrhea, bloating, abdominal distension could be significantly ameliorated by restoring microbiota balance. Intestinal flora analysis is expensive and is not available as routine test, but dysbiosis could be described based on symptomatology. Probiotics could be helpful in dysbiosis prevention or amelioration.

\section{Nutritional intervention in COVID-19}

What type of nutritional approach is recommended? The experience from Zhejiang University ${ }^{(36)}$ is showing that critically illness in the infection with SARS-CoV-2 presents a high nutritional risk. Gastrointestinal evaluation, aspiration risk, should be part of early evaluation of risk and are important for patient prognosis. Nutritional support should prefer oral feeding, whenever is possible. A special attention should be dedicated to a healthy microbiome and intestinal immunity. Energy intake should be 25-30 kcal/ body weight, with $1.2-2 \mathrm{~g} / \mathrm{kg}$ proteins. Enteral nutrition will be recommended in severe cases. For patients 
with intestinal damage specific products with predigested short proteins that will be easily absorbed will be appropriate. Whole protein preparations, rich in calories will be selected when the patient has a preserved intestinal function. Vitamin $D$ role ${ }^{(37)}$ in reducing infections risk has been explained through defensins and cathelicidins, with a lower viral replication activity and reduction of proinflammatory citokines activity. Evidence is supporting the recommendation that for people at risk of developing COVID-19 to consider for few weeks a dosage of $10000 U 1 /$ day of vitD3, than a maintainance dose of $5000 \mathrm{UI} /$ day. The target must be to stabilize a level of $40-60 \mathrm{ng} / \mathrm{ml}$ for $25(\mathrm{OH}) \mathrm{D}$ concentration.

\section{After COVID 19 - further lifestyle recommendations}

Pulmonary rehabilitation measures, based on Chinese front-line experience ${ }^{(36)}$ are starting with ameliorations of symptoms like: dyspnea, depression, anxiety during the treatment period in hospital, for moderate cases, but will continue as part of a healthy lifestyle for future, after patients recovery.

Smoking cessation, mandatory during the illness should be a priority also in recovery period.

A healthy lifestyle, with normalizing body weight, a healthy nutrition model, adapted to caloric and nutritive requirements, daily physical activity and an optimal sleep, mindfulness will remain key principle for a healthy future for patients after COVID-19.

\section{The other side: Quarantine and COVID- 19}

The quarantine period could be described as an "obesogenic" period. Since obesity and COVID-19 could be named the coalition of two pandemic crisis, a special attention should be paid to people living on the other side. In quarantine, sedentarism is favorized, stress will increase the tendency to eat hypercaloric foods, to eat mindlessly. Mass quarantine potential benefits should be managed carefully against long term increase in cardiovascular risk. Unhealthy lifestyle and anxiety should be approached carefully. Simple healthy lifestyle messages should be emphasized in order to encourage correct nutrition, exercises, stress management, sleep optimization, smoking cessation and alcohol consumption in moderation.

\section{Conclusions}

Facing this pandemic coalition, our messages should be stronger in stimulating prevention of obesity. Since more than a half of Romanian population is already overweight or obese, healthy lifestyle should become a daily prescription, not just a luxury recommendation. Daily we should encourage people to do more in acknowledging calories, fruits, vegetables, cereals, qualitative proteins and low saturated fat intake.

Daily, right messages from doctors acting like ROLE MODELS, in a partnership between general practitioner and other specialties like diabetologists, pneumologists, cardiologists, nutritionists will be efficient weapons against this cruel coalition: Obesity and COVID 19.

\section{References}

1. WHO characterizes COVID-19 as a pandemic. (11 March 2020); Available from: https://www.who.int/ emergencies/diseases/novelcoronavirus- 2019/eventsas-they-happen. WHO Director-General's opening remarks at the media briefing on COVID-19 - 11 March 2020. (23 March 2020); Available from: https://www.who.int/dg/speeches/detail/who-directorgeneral-sopening- remarks-at-the-media-briefing-oncovid-19\%2D\%2D-11-march-2020)

2. GuanWJ, Ni ZY, Hu Y, et al. Clinical characteristics of coronavirus disease 2019 in China. N Engl J Med. 2020 


\section{Feb;28 Epub}

3. Caspard H, Jabbour S, Hammar N, Fenici P, Sheehan $\mathrm{J}$, Kosiborod M (2018) Recent trends in the prevalence of type 2 diabetes and the association with abdominal obesity lead to growing health disparities in the USA: an analysis of the NHANES surveys from 1999 to 2014. Diabetes Obes Metab 20(3):667-67

4. Roser M, Ritchie $H$, Ortiz-Ospina E, Coronavirus Disease (COVID-19). Research and Statistics. University ofOxford, 2020

5. Puig-Domingo M, Marazuela M, Giustina A. COVID19 and endocrine diseases. A statement from the European Society of Endocrinology. Endocrine. 2020;68(1):2-5. doi:10.1007/s12020-020-02294-5).

6. S. Popa, M. Moța, A. Popa et al; "Prevalence of overweight/ obesity, abdominal obesity and metabolic syndrom and atypical cardiometabolic phenotypes in the adult Romanian population: Predatorr study, J. Endocrinol.Invest. Springer, published online 28th of April 2016

7. Sideleva $O$, Suratt $B T$, Black KE, et al. Obesity and asthma: an inflammatory disease of adipose tissue not the airway. American journal of respiratory and critical care medicine 201210 1;186(7):598-605

8. Polotsky VY, Smaldone MC, Scharf MT, et al. Impact of interrupted leptin pathways on ventilatory control. J Appl Physiol (1985) 2004 3;96(3):991-8. doi: 10.1152/japplphysiol.00926.2003. (PubMed: 14578371)

9. Bassi M, Furuya WI, Menani JV, et al. Leptin into the ventrolateral medulla facilitates chemorespiratory response in leptin-deficient (ob/ob) mice. Acta Physiol (Oxf) 2014 5;211(1):240-8. doi: 10.1111/apha.12257. (PubMed: 24521430)

10. L. F, C. J, A. H, et al. Obesity is associated with higher risk of intensive care unit admission and death in influenza A (H1N1) patients: a systematic review and meta-analysis. Obesity Reviews 2011;12(8):653-659. doi: doi:10.1111/j.1467-789X.2011.00864.x. (PubMed: 21457180)

11. Ubags ND, Stapleton RD, Vernooy JH, et al.
Hyperleptinemia is associated with impaired pulmonary host defense. JCI Insight 2016 6;1(8). doi: 10.1172/jci.insight.82101.

12. Shah D, Romero F, Duong $M$, et al. Obesity-induced adipokine imbalance impairs mouse pulmonary vascular endothelial function and primes the lung for injury. Sci Rep 2015 6;5:11362. doi: 10.1038/srep11362. (PubMed: 26068229)

13. Agrawal A, Mabalirajan U, Ahmad T, et al. Emerging interface between metabolic syndrome and asthma. Am J Respir Cell Mol Biol 2011 3;44(3):270-5. doi: 10.1165/rcmb.2010-0141TR. (PubMed: 20656947)

14. Zaigham S, Nilsson PM, Wollmer $P$, et al. The temporal relationship between poor lung function and the risk of diabetes. BMC Pulm Med 2016 5;16(1):75. doi: 10.1186/s12890-016-0227-z. (PubMed: 27165091)

15. Brittain EL, Nwabuo C, Xu M, et al. Echocardiographic Pulmonary Artery Systolic Pressure in the Coronary Artery Risk Development in Young Adults (CARDIA) Study: Associations With Race and Metabolic Dysregulation. J Am Heart Assoc 2017 3;6(4). doi: 10.1161/JAHA.116.005111.

16. Ford ES, Cunningham TJ, Mercado Cl. Lung function and metabolic syndrome: Findings of National Health and Nutrition Examination Survey 2007-2010.J Diabetes 2014 11;6(6):603-13. (PubMed: 26677470)

17. Gabriela P. Peralta GP, et al. Body mass index and weight change are associated with adult lung function trajectories: the prospective ECRHS studyThorax 2020

18. 18. Weisberg SP, McCann D, Desai M, et al. Obesity is associated with macrophage accumulation in adipose tissue. J Clin Invest 2003 12;112(12):1796-808. doi: 10.1172/JCl19246. (PubMed: 14679176)

19. Periyalil HA, Wood LG, Wright TA, et al. Obese asthmatics are characterized by altered adipose tissue macrophage activation. Clinical and experimental allergy : journal of the British Society for Allergy and Clinical Immunology 20181 31. doi: 10.1111/cea.13109 20. Puig-Domingo M, Marazuela M, Giustina A. COVID19 and endocrine diseases. A statement from the European Society of Endocrinology. Endocrine. 
2020;68(1):2-5.

21. Anderson CJ, Murphy KE, Fernandez ML, Impact of obesity and metabolic syndrome on immunity. Adv Nutr 2016, 7:66-77.

22. Ouchi N, Parker JL, Lugus JJ, Walsh K, Adipokines in inflammation and metabolic disease. Nat Rev Immunol, 2011,11(2):85-97.

23. Richard C, Wadowski M, Goruk S et al (2017) Individuals with obesity and type 2 diabetes have additional immune dysfunction compared with obese individuals who are metabolically healthy. BMJ Open Diabetes Res Care 5(1)

24. Ahn SY, Sohn SH, Lee SY et al, The effect of lipopolysaccharide- induced obesity and its chronic inflammation on influenza virus-related pathology. Environ Toxicol Pharmacol, 2015,40(3):924-930

25. Xue K, Stevens-Ayers T, Campbell AP et al ,Parallel evolution of influenza across multiple spatiotemporal scales, 2017, eLife 2017;6:e26875

26. Zheng Q, Cui G, Chen J et al, Regular exercise enhances the immune response against microbial antigens through upregulation of toll-like receptor signaling pathways. Cell Physiol Biochem 37:735-746), 2015

27. Luzi L.,Radaelli M.G.- Influenza and obesity: its odd relationship and the lessons for COVID-19 pandemicActa Diabetologica https://doi.org/10.1007/s00592020-01522-8)

28. Maier H, Lopez R, Sanchez $N$ et al, Obesity increased the duration of influenza $A$ virus shedding in adults. J Infect Dis 2018, 218(9):1372-1382

29. Klinkhammer J, Schnepf D, Ye L et al , INF-lambda prevents influenza virus spread from the upper airways to the lungs and limits virus transmission 2018, elife 7:e33354

30. Yan J, Grantham M, Pantelic J et al , Incetious virus in exhaled breath of syntomatic seasonal influenza cases from a college community, 2018, PNAS 115(5):1081-1086)
31. Donna H. Ryan, Eric Ravussin, and Steven Heymsfield COVID 19 and the Patient with Obesity - The Editors Speak Out The Obesity Society. Published online 1 April 2020. 2020 Apr 9. doi: 10.1002/oby.22831. (Epub ahead of print)

32. Jennifer Lighter, Michael Phillips, Sarah Hochman, Stephanie Sterling, Diane Johnson, Fritz Francois, Anna Stachel, Obesity in patients younger than 60 years is a risk factor for Covid-19 hospital admission Published by Oxford University Press for the Infectious Diseases Society of America, April 10, 2020

33. Simonnet A, Chetboun M, Poissy J, Raverdy V, Noulette J, Duhamel A, Labreuche J, Mathieu D, Pattou F, Jourdain M; Lille Intensive Care COVID-19 and Obesity study group, High prevalence of obesity in severe acute respiratory syndrome coronavirus-2 (SARS-CoV-2) requiring invasive mechanical ventilation, Obesity ( Silver Spring ) 2020 April 9.

34. Zhou F, Yu T, Du R, et al. Clinical course and risk factors for mortality of adult inpatients with COVID-19 in Wuhan, China: a retrospective cohort study. The Lancet 2020;395:1054-1062.

35. Kerkhove MDV, Vandemaele $K A H$, Shinde $V$, et al. Risk Factors for Severe Outcomes following 2009 Influenza A (H1N1) Infection: A Global Pooled Analysis. PLOS Medicine 2011;8:e1001053

36. Handbook of COVID-19 Prevention and Treatment, Compiled According to Clinical Experience, The First Affiliated Hospital, Zhejiang University School of Medicine, 2020

37. William B Grant, Henry Lahore et al, Evidence that Vitamin D Supplementation Could Reduce Risk of Influenza and COVID-19 Infections and Deaths, Nutrients, April 2020

38. Anna Vittoria Mattioli, MD, $P h D$, and Matteo Ballerini Puviani, MSc Lifestyle at Time of COVID-19: How Could Quarantine Affect Cardiovascular Risk, American Journal of lifestyle medicine, April 2020, vol XX, noX 